\title{
Técnica de los cuentos de Manuel Gutiérrez Nájera *
}

I estudiar los elementos dispersos en la producción cuentística A del Duque Job, se notan rasgos típicos, presentes en diferentes tipos de cuentos, que revelan tendencias personales de su creador, y de las cuales se puede deducir características de la técnica literaria de Gutiérrez Nájera, tan distinta de la de otros autores.

Con el debido respeto a los juicios literarios de los literatos contemporáneos de Gutiérrez Nájera, que atribuian su falta de producción de géneros literarios elevados, como la novela, a las tareas agobiantes del periodismo, en las cuales tuvo el Duque Job que luchar para obtener el pan diario, fuerza es reconocer que el talento de Gutiérrez Nájera no se prestaba a tales géneros, por faltarle los recursos necesarios para su creación, pero dentro del género del cuento dejó valiosas joyas, y en él mostró sus dotes de artista de elevada inspiración. El elemento indispensable de la novela es narración de acontecimientos presentados en ilación de tiempo, una de las cualidades más débiles en las creaciones del Duque. Sabemos el fracaso que siguió a su esfuerzo pata escribir la novela La mancha de lady Macbeth. ${ }^{2}$ El plan premeditado y complejo que exige el gé-

* Páginas del capítulo v de la tesis sobre "Los cuentos de Manuel Gutiérrez Nájera", presentada por su autor para optar el grado de Doctor en Filosofia, en University of Southern California. Los Angeles, Calif., en junio de 1954. 
nero novelesco y el desarrollo espiritual del personaje en el transrurso de los años no entraban en las disposiciones naturales del Duque Job y la costumbre de escribir con precipitación aumentaba la dificultad. En cambio, sus dotes se prestaban naturalmente al género del cuento que, de por sí, permite a sus creadores la libertad casi ilimitada de emplearlas según sus inclinaciones. Verdad es que el público moderno no está dispuesto a reconocer como grande al escritor a menos que escriba novelas, aunque los ejemplos de Chejov y Maupassant sean muy elocuentes para demostrar la posibilidad de alcanzar elevación en el dominio de la narración corta.

\section{Género del cuento: definición, principios de Poe}

Como punto de partida del capítulo presente conviene fijar la atención sobre las propiedades del género literario que constituye el cuento, para determinar la aportación de Gutiérrez Nájera a este género y el lugar que le corresponde entre otros cuentistas.

Federico de Onís, en su prólogo a la Antología de cuentos españoles, of rece la siguiente definición del cuento en el sentido literario:

La palabra cuento se ha aplicado y se aplica a diversos modos de narración, que a veces se han designado también con otros nombres. Modernamente se usa para denominar, por una parte, unı relato oral y casi siempre tradicional, como los que cuentan las madres a sus hijos, y por otra, un cierto género de narración novelesca escrita que se distingue fácilmente de la novela por su corta extensión y por las cualidades estéticas que tal limitación en el tamaño determina. No es, por lo tanto, solamente el tamaño lo que establece la diferencia entre la novela y el cuento: puede ocurrir que una narración corta responda a la concepción episódica y sintética del cuento, y entonces esa novela condensada en breve espacio se denomina novela corta. Estas tres denominaciones - novela, novela corta y cuento- se usan comúnmente en espafiol moderno para designar tres géneros de narración novelesca que se suponen por críticos $y$ autores esencialmente distintos. ${ }^{3}$

The Encyclipedia Americana amplía el concepto, adaptándolo a los cuentos modernos: 
Short Story. Characteristics.

The definitive nature of the short story is implicit in the adjective and noun comprising its name. As a story, it narrates a series of events, or a single incident, involving individuals in mental or physical activity. Thus, like all fiction, it portrays; and its success depends upon the immediacy achieved between the reader and the object portrayed. As a short story, however, it can not effect this immediacy by the means common to the novel, such as characterization, detailed description, and repetition. Instead, it must portray with mirror-like swiftness and completeness.

For this reason, the short story is most powerful through graphic narration. This is not to say that its subject matter can be only simple and realistic. Of all literary forms the short story is in fact the least restricted in subject matter, for ist length permits treatment of subjects that could not alone sustain interest in a longer form. From carliest times, the short story has served as allegory, fable, and moral example. It has drawn themes from matter supernatural and natural, romantic and realistic, grotesque and mundane. The abnormal personality, as well as the representative one, may be portrayed by it; mental processes as well as physical action; casual happening as well as arresting incident. All these have a place in the short story, provited the are translated into the concrete. Growing consciousness of this necessity has forged the techniques that made possible significant short-story writing. ${ }^{4}$

Desde la época de Giovanni Boccaccio (1313-1375) y Geoffrey Chaucer (1340 ?-1400), eminentes cuentistas del Renacimiento, hasta la segunda mitad del siglo xix, época de Gutiérrez Nájera, el género del cuento ha experimentado periodos alternativos de florecimiento y decadencia. En el siglo XIX las grandes posibilidades de la narración corta han sido utilizadas por los literatos de ambos continentes. En este género, acaso más que en ningún otro, al autor se le facilita expresar su personalidad, pues en el concepto moderno el asunto del cuento no se rige por moldes fijos.

En los Estados Unidos se considera generalmente a Edgar Allan Poe como padre del cuento moderno. En efecto, el cuentista norteamericano comparte el laurel con el novelista ruso, Gogol, como lo atestigua $H$. E. Bates, en su bosquejo sobre los dos escritores: 
Nicolai Vasilievitch Gogol was born at Sorotchinsky, in Russia, in 1809; in exactly the same year Edgar Allan Poe was born in Baltimore. Gogol was educated at Niezhin; Poe at Stoke Newington in England. Gogol died in 1852, Poe in 1849. And from these two short lives may be said to flow the twin streans of the modern short story. 5

A Poe, sin embargo, pertenece el gran mérito de haber formulado.los principios generales del género cuentístico moderno, que se pueden adaptar a una gran variedad de cuentos de diversos tipos: (1) El tamaño del cuento no debe exceder el período de lectura dentro de una sola sesión; (2) El diseño concebido debe llevarse a cabo, para que el lector reciba la impresión de finalidad; (3) $\mathrm{El}$ cuento debe crear un efecto único; (4) No debe contener ni una palabra que no tienda a cumplir el diseño concebido. ${ }^{6}$ Como se echa de ver en estos principios, una inmensa variedad de temas puede servir de asunto para el cuento, los cuales se subordinan al efecto obtenido.

Sea que Gutiérrez Nájera estuviera enterado de la crítica literaria de Poe o que no, sus cuentos caben dentro de los preceptos de este género establecidos por el crítico y cuentista norteamericano.

II

TECNICA DE LOS CUENTOS DE GUTIERREZ NAJERA

Quedan establecidos los puntos de partida del capítulo presente: las dotes individuales del Duque Job como un escritor y los caracteres del género cuentístico. Pasemos al estudio de los elementos técnicos contenidos en los cuentos de Gutiérrez Nájera, adoptando el plan siguiente:
A. Temas
B. Construcción.
C. Tipos humanos.
D. Temas de otros cuentistas.
E. Elementos idiosincrásicos: 

(1) fantasía.
(2) filosofía.
(3) estilo.

\section{A. TEMAS}

Todo escritor, al marchar por la senda de la existencia humana, forma su propia imagen de la vida, su propia idea de la realidad. Examinando las obras de un escritor al granel, se percibe qué incidentes de la vida atraen su atención, qué situaciones escoge, y qué tipos humanos le interesan. Un estudio semejante permite establecer un concepto definitivo, según el cual se revela la personalidad literaria del escritor en términos coherentes de caracteres individuales. Chejov, Maupassant, Poe, Stevenson, para mencionar sólo unos cuantos, encajan en sus cuentos incidentes de índole diversa, crean a sus personajes de conformidad con su propio ente espiritual e interpretan la vida según su concepto personal. Por eso los temas presentados varian según su creador $y$, aunque se repitan, parecen siempre frescos, eternamente virginales.

Maupassant afirma el principio de la selección individual de temas en forma que clarifica su propio caso:

La vie... est composée des choses les plus différentes, les plus impréznes, les plus contraires, les plus disparates; elle est brutale, sans suite, sans chaine, pleine de catastrophes inexplicables, illogiques et contradictoires qui doivent être classées au chapitre faits divers.

Voila pourquoi l'artiste, ayant choisi son thème, ne prendra dans cette vie encombrée de hasards et de futilités que les détails caractéristiques utiles a son sujet, et il rejettera tout le reste, tout l'à-côté. ${ }^{7}$

Nuestra percepción personal del mundo no es otra cosa que una ilusión que varía según el individuo, y la misión del escritor es la de reproducir su propia ilusión en forma artística: 
Chacun de nous se fait donc simplement une illusion du monde, illusion poétique, sentimentale, joyeuse, mélancolique, sale ou lugubre suivant sa nature. Et l'écrivain n'a d'autre mission que de reproduir fidelement cette illusion du laid qui est une opinion changeante! Illusion du vrai jamais immable! Illusion de lignoble qui attire tant d'êtres! Les grands artistes sont ceux qui imposent à l'humanité leur illusion particulière. 8

Los temas de Gutiérrez Nájera llaman al corazón, al sentimiento y no a la razón. Nunca figura en ellos una idea intelectual, sino las pasiones humanas, con predominio del ambiente de fracaso.

¿Qué incidentes de la vida son inspiradores de Gutiérrez Nájera para sus obras literarias? Los de motivos trágicos: el amor fracasado, las ilusiones perdidas, las injusticias humanas, el triunfo del mal, con un desenlace fatal de la muerte prematura, o un aniquilamiento espiritual de los protagonistas. De la colección de veintiún cuentos, el mencionado carácter de la muerte finaliza con los personajes principales en once cuentos. Mueren: Alicia en La venganza de Mylord, la niña Rosalía en La pasión de Pasionaria, el joven en Los suicidios, el tercer músico en El músico de la murga, el personaje principal de Rip-Rip, el protagonista de Juan el organista, RosaThé en Dame de coeur, la familia de la mexicanita en Un 14 de julio, Blanca en el Cuento triste, Gabriel y Carlos en La mañana de San Juan, el bebé en La balada de año nuevo. Hay un espectro de la muerte en El vestido blanco, cuando Adrián, el padre, prevé el sudario de su hija que le sugiere el color blanco. Mueren trágicamente la mamá y la hermanita del "inglesito" en la Historia de un peso falso. El muchacho, aunque no muere físicamente, queda aniquilado como el personaje risueño del cuento, empezando la vida de un criminal en la Correccional. Para la "hija del aire", en el cuento del mismo nombre, Gutiérrez Nájera desea la muerte como libertadora de sus suplicios. Parece que la imagen de la muerte siempre está presente en la mente del Duque.

El amor fracasado sirve de tema en seis cuentos: La venganza de Mylord, El músico de la murga, Rip-Rip, Juan el organista, Dame de coeur, Cuento triste. $\mathrm{El}$ amor en el tratamiento del Duque Job es una pasión ardiente que consume a sus víctimas. No hay un solo caso de amor feliz. Los obstáculos que encuentran los amantes son insuperables a tal grado que acaban con su vida. 
Estrechamente ligado con el tema del amor fracasado está el tema de las ilusiones perdidas. Rip-Rip idealizaba a su mujer y al amigo Juan "el del molino" y no puede soportar el rudo golpe de que ambos son adúlteros y traidores.

Dos de los músicos, presentados en El músico de la murga, están aniquilados espiritualmente a causa de ilusiones quebradas. Uno, el pianista Pomar, personaje de Federico Gamboa, cansado de entretener al vulgo soez con los bailecitos triviales, arrastra la vida de una rutina odiosa. El violinista de talento superior, "el de los ojos azules desteñidos", 9 también obligado a tocar música de bailes, para él detestable, está aniquilado por no actuar como verdadero artista, lo cual le clava al alcoholismo, que le mata. La bella Manón, en después de las carreras, que fué rica, queda anulada por su presente estado de sirvienta y padece del quebranto en sus ilusiones juveniles, añorando con triunfos, fiestas y galanes. El suicida, en Los suicidios, empieza su carta así: "Caballero voy a matarme porque no tengo una sola moneda en mi bolsillo, ni una sola ilusión en mi cabeza." 10

Las injusticias de la vida y el triunfo del mal pasan como un hilo al rojo por todas las obras del Duque, pero como tema central aparece en La pasión de Pasionaria, donde la pequeña Rosalia muere víctima del maltrato de la madrastra; en la Crónica de mil colores, donde la astuta "Caperucita color de rosa" logra con sus intrigas apoderarse de los bienes del viejo barón de Saint-Loup. En la Historia de un peso falso, el "inglesito" cae victima de la cruel burla del atolondrado caballero que le regala un peso falso, por el cual el bueno e inocente niño es inhumanamente acusado de ladrón. La "hija del aire" está torturada por adiestradores desalmados que la explotan, a pesar de su fragilidad, para divertir al público ávido de placeres fútiles.

Sólo en cuatro cuentos no aparece el tema trágico. Dos de estos cuentos son de fantasía, sin base en la realidad: Los amores del cometa y La novela del tranvía. Los otros dos son de asuntos caricaturescos: El aloniler de una casa y la Historia de una corista. 


\section{B. CONSTRUCCION}

Sabiendo que Gutiérrez Nájera no retocaba sus cuentos, fácil es pensar que el escritor careciera de técnica literaria fija. Lejos tal cosa de la verdad. Examinando la producción cuentística del Duque en conjunto, se observa el empleo de principios generales, comunes a todos los cuentistas de primera línea, y además, se reconoce un sello personal que se manifiesta con infalible constancia, una manera de tratar el asunto, por sencillo que sea, que es la de Gutiérrez Nájera y de nadie más, la que presta a sus obras un encanto completamente suyo.

Anécdota. En el cuento moderno la anécdota como tal ha pasado al segundo término. Importa más el laberinto de relaciones humanas que el autor pone en escena, el hombre y la mujer presentados según el concepto del autor, los personajes que obran de formas raras e imprevistas, distintas de las de sus prójimos, y el juicio del autor acerca de la conducta de sus personajes, el criterio en concordancia con su propio temperamento y personalidad literaria, no repetidos en ningún otro caso. En una gran parte de los cuentos de Chejov "nada pasa" y, sin embargo, son obras maestras. En Maupassant la anécdota tiene más substancia, pero en sus cuentos tampoco es la anécdota la que los hace perdurables, sino la humanidad en sus mutuas relaciones que pinta el autor. En La ficelle ( $L a$ cuerdecita), ${ }^{11}$ por ejemplo, el punto cardinal que destaca Maupassant es la crueldad humana que se revela por medio del asunto.

En Gutiérrez Nájera la anécdota tiene una importancia secundaria y es, a veces, floja. El hecho de que el escritor no construía sus cuentos según un plan premeditado no favorecía asuntos bien desarrollados ni complejos. Sabemos que Chejov y Turgueneff $\mathbf{1 2}$ pulían sus cuentos con mucho esmero, cambiando y rehaciendo el plan original. ${ }^{13}$ En Gutiérrez Nájera el primer proyecto trasladado ai papel permanece sin cambios. De aquí resulta una construcción improvisada $\mathrm{y}$, a menudo, un tipo de cuento en que se presenta más que nada una situación, lo cual es, empero, una propiedad legítima del cuento moderno.

Cuentos de la "corriente de conciencia". La costumbre de escribir precipitadamente, sin profundizar el primer proyecto, deter- 
mina en la mayoría de los cuentos del Duque, parcial o totalmente, lo que actualmente se llama la "corriente de conciencia". Cuentos representativos de esta orientación son Los amores del cometa y La novela del tranvía. ${ }^{14}$ En ésta no sabemos un solo detalle de la vida verdadera de los dos vecinos del autor en el tranvia, quien revela únicamente sus propios pensamientos sobre la personalidad y la vida de ellos que improvisa en el papel. En este caso no es el asunto lo que deleita al lector, sino el artífice en el proceso de creación de una tarea fina. La técnica que el autor emplea inconscientemente forja la ilusión de la realidad, atenuando la inverosimilitud. Los amores del cometa muestra la extraordinaria imaginación del autor cuando corre a rienda suelta, mientras observa los fenómenos celestiales. Al mismo tipo de cuentos de la "corriente de conciencia" pertenecen: En el hipódromo, El músico de la murga, El vestido, blanco, La hija del aire. En estos cuentos presenciamos la vida de personajes, vista a través de la mente de Gutiérrez Nájera, de sus actitudes, de sus estados anímicos, y de sus gustos $\mathrm{e}$ inclinaciones.

Cuentos narrativos. Sin embargo, hay cuentos de Gutiérrez Nájera en que se narra una historia, apartándose el autor a un segundo plano, aunque el lector nota en el ambiente la presencia invisible de la persona que mueve los hilos del "guignol." En éstos la acción de los personajes revela el sentido omnisciente del autor que escoge situaciones que le cuadran, personajes que le atraen, entra en la mente de ellos, analiza sus emociones, les observa desde fuera y tiene el absoluto dominio de las figuras que crea. De esta índole son: Historia de un peso falso, Rip-Rip, Juan el organista, Un 14 de julio, La mañana de San Juan, La balada de año nuevo. Estos cuentos son representativos de la clase de incidentes en la vida que mueven al autor en el impulso de moldear las imágenes que le inspiran.

Un 14 de julio ${ }^{15}$ es un buen ejemplo de como un artista es capaz de tomar una breve noticia periodística, seca, desnuda de imaginación, e inspirarle vida, inyectarle nueva savia, de suerte que los muñecos yertos adquieran sentimientos humanos, sufran, amen, hablen al alma del lector. El asunto es sencillo y puede ser referido en pocas frases: Una mexicana casa con un pobre pintor francés. No encuentran medios para vivir en México y el matrimonio, con 
sus seis hijos, se traslada a Paris, donde, impulsados por el hambre, se suicidan por asfixia, el 14 de julio, el día de la fiesta nacional. Gutiérrez Nájera refiere esta historia de un modo personal, con gran técnica. Introduce a la heroína, la mexicanita, con el pretexto moral de compasión cristiana:

Voy a referiros una breve y triste historia, y voy a referirla porque hoy habrá muchos semblantes risueños en las calles, y es bueno que los alegres, los felices, se acuerden de que hay algunos, muchos desgraciados. Es un episodio del 14 de julio, pero no del 14 de julio de 1789 , sino del 14 de julio de 1890 . Y la heroína es una paisana nuestra, una hermosa y desventurada mexicana. 16

Según el autor es una mujer notable, lo. cual intensifica el contraste para el horripilante desenlace:

¡Ah! De ella hablaron mucho los diarios de París hace dos años: más que de Mme. Iturbe y de sus trajes, más que de la señorita Escandón y de su boda. Arsenio Houssaye, ese anciano coronado de rosas, le dedicó una página brillante, una aureola de oro como esas que circundan las sienes de las mártires. La piedad la amó un momento, un momento nada más, porque la piedad tiene siempre muchísimo que hacer. $\mathrm{Y}$ ahora que miro esas banderas, esas flámulas, esos gallardetes, símbolos de noble regocijo, pienso en la pobre mexicanita que pasó en París el 14 de julio de 1890.17

París, inmensa ciudad, indiferente a los sufrimientos humanos, se describe con colores de resignada tristeza: " $i$ Es tan grande París! ¡Hay en sus calles tanto ruido! ¡Es tan difícil percibir allí la voz de un hombrel" 18

Siente el autor predilección por los niños. Una descripción del estado creado por el hambre en términos objetivos no hallaría en el lector un eco de compasión tan intenso como oír hablar al niño famélico :

-Mamá, ¿Qué cosa es morir?

-Morir, hijito, es irse al cielo.

- ¿Y cómo será el cielo? ¿como el mar?

-No; el cielo es un jardín en donde hay muchas flores y muchas frutas y muchos juguetes para los niños.

-Sí, pero no serán para mí. También aquí hay todo eso y nada es mío. 
-En el cielo cogen los niños que no son traviesos cuanto quieren.

-i Mamá, vamos al cielo! 19

Para crear un efecto de horror, al describir la muerte de la familia, utiliza Gutiérrez Nájera el recurso de repetir imágenes afines:

No hubo necesidad de que apagaran la vela. También ella se apagó. Ardía el carbón, $\dot{y}$ su fulgor dantesco semejaba un boquete del infierno asomando en la sombra. ¿Quién llora? ¿Quién solloza? ¿Quién se queja? ¿Quién se retuerce? ¿Quién sofoca blasfemias? ¿Quién se ahoga? ${ }^{0}$

La conclusión del cuento proporciona una culminación en la que el pensamiento del autor se desborda en lamentos emotivos, apelando a Dios, técnica de frecuente uso por Gutiérrez Nájera.

\section{Recursos de técnica literaria: unidad de lugar, de tiempo y de personaje}

Unidad de lugar. Gutiérrez Nájera sitúa la acción de dieciocho de sus cuentos en México, y principalmente en la capital. En La pasión de Pasionaria y en la Crónica de mil colores no hay mención de lugar. La acción de Un 14 de julio es París. El autor nunca traspasó los límites de su patria y las imágenes que evoca su cerebro se colocan inconscientemente en el suelo donde nació y en la ciudad en que vivió. Como es propio del género, el Duque mantiene la narración de sus cuentos dentro del mismo escenario, con frecuencia un hogar, como en: Dame de coeur, Cuento triste, Un 14 de julio, La balada de año nuevo, Después de las carreras, Tragedias de actualidad, El alquiler de una casa, La pasión de Pasionaria. A veces, es un edificio público: El músico de la murga (salones de baile), El vestido blanco (iglesia), La hija del aire (circo), La venganza de Mylord, primera parte (teatro), Juan el organista (casa e iglesia). Los lugares extraños a la casa son: la calle y el garito (Historia de un péso falso); el hipódromo ( $E_{n}$ el hipódromo); el parque de Chapultepec (La venganza de Mylord, segunda parte); 
la calle y la casa (Crónica de mil colores, Rip-Rip); la presa (La balada de año nuevo).

En dos cuentos, escritos en forma epistolar, los limites se circunscriben a las páginas de las cartas (Los suicidios, Historia de una corista). En un cuento de pura imaginación, Los amores del co$m e t a$, el escenario es el universo entero, pero reducido al tamaño comprendido en los límites del concepto antropomórfico del autor. El local del otro cuento imaginativo, La novela del tranvia, es el cerebro del autor quien conjetura cuadros de la vida de sus vecinos del tranvía, sin ninguna base en la realidad. Gracias a la unidad de lugar, la atención del lector puede concentrarse en los elementos artísticos del cuento.

Unidad de tiempo, aceleración, retardación. Los episodios dramáticos que Gutiérrez Nájera considera dignos de narración se verifican en la mayoría de los casos dentro de cortos períodos de tiempo. El lector no aprecia cuanto es el tiempo, seducido por la destreza del autor, quien cuida de que el desenlace se produzca, generalmente, en un solo día. Así aparece en diecisiete cuentos. En los restantes cuentos, el autor aisla los momentos dramáticos que merecen la presentación y les agrega fragmentos del pasado que guardan relación directa con la esencia del asunto.

El problema del tiempo en los cuentos de Gutiérrez Nájera, como en los de cualquier otro escritor, permite apreciar cual es el arte del autor para manejar los episodios que constituyen la narración. Tanto que el cuento cubra una vida entera como una ahora, el problema para el escritor es equivalente. Ningún episodio vale la pena de la narración minuto a minuto, salvo si las ocurrencias que llenan tales minutos son significativas. Cuando el autor ha escogido los asuntos centrales del tema, su tarea es la de aislar la hora en que se verifican $y$, además, la de engancharla con aquellos episodios del pasado que pueden tener relación directa con el presente. No importa si para justificar la hora preferida el autor arranca del día anterior o de veinte años del pasado, con tal de que mantenga la unidad del tema central. En Juan el organista ${ }^{21}$ el tema central es el amor desdichado de Juan hacia Enriqueta. El autor empieza su narración cuando Juan, a los treinta años de edad, viene a la hacienda de don Pedro en busca de empleo.Para dar razón de toda la vida anterior del protagonista el Duque se vale del acelera- 
dor, escogiendo sólo aquellos hechos del pasado del joven que permiten explicar su ente presente: origen, educación y oficio. Con una página es suficiente para llevar al lector al infausto casamiento de Juan con Rosa, el hecho que causa su ruina.

En la Crónica de mil colores ${ }^{22}$ el asunto se verifica dentro de un período de tres años. $\mathrm{El}$ autor presenta a la protagonista, "Caperucita color de rosa", a la edad de trece años y el desenlace se efectúa cuando tiene dieciséis años. El intervalo de tiempo no se nota, pues el Duque sostiene la constancia de los rasgos de la heroina.

En Los suicidios ${ }^{23}$ y en la Historia de una corista, ${ }^{24}$ ambos cuentos escritos en forma epistolar, donde los supuestos autores narran su vida desde la niñez, hay idéntico recurso de aceleración, que permite mantener la unidad de narración. En estos dos cuentos el nexo es el conjunto de causas, psicológicas en el primer caso y materiales en el segundo, que conducen al suicidio del hombre y a la vida resbaladiza entre bastidores de la mujer.

El recurso literario opuesto, el del retardador, es también empleado por Gutiérrez Nájera. A causa de ser extremadamente subjetivo, el autor se halla más interesado en la vida emotiva y en los estados anímicos de la humanidad que en la acción o acontecimientos de la vida. Para expresar tales estados utiliza toda la vehemencia de sus sentimientos, y el Duque se detiene en los momentos de mayor fuerza, destacándolos en la acción.

En La balada de año nuevo, por ejemplo, retrata con su acostumbrada facilidad para dar matices, los estados emotivos de Clara, la doliente madre, y su profunda angustia al presenciar los últimos momentos de la vida del bebé, mientras el doctor escribe una receta. En el espacio de dos páginas el autor exhibe toda la gama de emociones de la joven madre, su muda protesta al ver la incapacidad del médico de salvar al niño, su voluntad vehemente de sustituir al niño en su martirio y su desesperación al contemplar al enfermito:

Clara no llora; ya no tiene lágrimas. $Y$ luego, si llorara, despertaría a su pobre niño. ¿Qué escribirá el doctor? ¡ Es la receta! iAh, si Clara supiera lo aliviaría en un solo instante! Pues qué, ¿nada se puede contra el mal? ¿No hay médicos para salvar una existencia que se apaga? iAh!, si los hay; si debe haberlos; Dios es bueno; Dios no quiere el suplicio de las madres; los médicos 
son torpes, son desamorados; poco les importa la honda aflicción de los amantes padres; por eso Bebé no está aliviado aún; por eso Bebé sigue muy malo; i por eso Bebé, el pobre Bebé, se va a morir! Y Clara dice, con el llanto en los ojos:

-iAh!, si yo supiera...

La calma insoportable del doctor la irrita. ¿Por qué no-lo salva? ¿Por qué no le devuelve la salud? ¿Por qué no le consagra todas sus vigilias, todos sus afanes, todos sus estudios? ¿Qué, no puede? Pues entonces de nada sirve la Medicina: es un engaño, es un embuste, es una infamia. ¿Qué han hecho tantos hombres, tantos sabios, si no pueden ahorrar este dolor al corazón, si no pueden salvar la vida a un niño, a un ser que no ha hecho mal a nadie, que no ofende a ninguno, que es la sonrisa, y es la luz, y es el perfume de la casa?

$\mathrm{Y}$ el doctor escribe...25

Unidad de personaje. Una novela que cincela al protagonista sobre una base amplia puede abarcar varias fases de su desarrollo $y$, algunas veces, un cambio total de su ente espiritual. En una narración corta tal cambio sería inusitado. Al observar los personajes de Gutiérrez Nájera notamos que todos ellos mantienen su entidad primordial por todo el curso de los cuentos. Como el autor les presenta ya integrados dentro de cierto tipo, el desenlace se verifica según la lógica implacable de las imágenes concebidas. En los cuentos ya están listos para desempeñar el papel que les conduce al desenlace, según se verá en la discusión de tipos humanos en los cuentos de Gutiérrez Nájera.

Suspensión. Uno de los medios más efectivos para mantener el interés narrativo del lector es la suspensión para el desenlace. En los cuentos con la anécdota mejor desarrollada este interés se intensifica mientras se aproxima el final. En cuentos subjetivos como lo son los de Gutiérrez Nájera, también hay suspensión, no en la marcha de la acción, sino en el proceso de los estados emotivos. Veamos, como ejemplo, Juan el organista. El Duque pinta con destreza técnica los arranques sentimentales de su romántico héroe, arrastrado por la pasión invencible hacia Enriqueta, en forma semejante a variaciones sobre un tema en lenguaje musical: 
Lo peor para Juan era el trato íntimo que tenía con Enriqueta. Vivía en su atmósfera y sentía su amor sin poseerlo, como se embriagan los bodegueros con el olor del vino que no beben. Cada día Juan encontraba un nuevo encanto en la mujer amada. Era como si asistiese al tocador de su alma y viera caer tuno a uno todos los velos que la cubrieran. Además nada hay tan invenciblemente seductor como una mujer hermosa en el abandono de la vida íntima. Juan miraba a Enriqueta cuando salía de la alcoba, con las mejillas calientes aún por el largo contacto de la almohada. Y la veía también con el cabello suelto o recostada en las rodillas de la madre. $Y$ cada actitud, cada movimiento, cada ademán, le descubrían nuevas bellezas. $E$ igual era el crecimiento de su admiración en cuanto atañe a la hermosura moral de Enriqueta. Todas esas virtudes que buscan la obscuridad para brillar y que nunca adivinan los profanos; todos esos atractivos irresistibles que la mujer oculta, avara, a los extraños, y de que sólo goza la familia, aumentaban la estimación de Juan y su cariffo. ${ }^{26}$

A partir de este punto eleva el autor la justificación del amor de Juan con la descripción del tierno afecto que sentía Enriqueta hacia Rosita, la hijita del enamorado:

Tenían además aquellas dos vidas un punto de coincidencia: Rosita. Enriqueta prodigaba a la niña todas las ternezas y cuidados de una madre joven; de una madre que fuera a la vèz como la hermana mayor de su hija. Cierta vez la niña enfermó. Fué necesario llamar a un doctor de México, cuyo viaje fué costeado por don Pedro. Enriqueta no abandonó un solo momento a la enfermita ...27

Ansía ya el lector el cumplimiento de la felicidad de Juan al lado de la mujer amada, cuando el Duque da entrada a un inesperado giro de los acontecimientos por.medio del rudo golpe del desengaño:

Juan fué al comedor de la hacienda. Habían servido ya la sopa, cuando don Pedro dijo en alta voz:

-Hoy es un día doblemente fausto. Rosita entra en plena convalescencia, y llega Carlos a la hacienda.

Luego, inclinándose al oído de Juan, agregó:

-Amigo mío, para usted no tenemos' secretos, porque es ya de la familia: Carlos es el novio de Enriqueta. 28 
Repetición. Este artificio que tiene por objeto aguzar los efectos dramáticos se emplea en los cuentos de Gutiérrez Nájera en distintas formas: (a) repetición de palabras simbolizando ideas que, después de repetidas, adquieren nuevos matices poéticos, como en la introducción a $E l$ vestido blanco:

\begin{abstract}
Mayo, ramillete de lilas húmedas que Primavera prende a su corpiño; Mayo, el de los tibios, indecisos stueños de la pubertad; Mayo, clarín de plata, que tocas diana a los poetas perezosos; Mayo, el que rebosa tantas flores como las barcas de Myssira... ${ }^{29}$
\end{abstract}

(b) en forma de repetición de términos sinónimos, como en $U n$ 14 de julio: "¿Quién llora? ¿Quién solloza? ¿Quién se queja? ¿Quién se retuerce? ¿Quién sofoca blasfemias? ¿Quiẻn se ahoga?" 30 (c) en forma más oculta, pero de uso frecuente, en la repetición de ideas expresadas con distintos símbolos, que permiten mantener la atención del lector en cierto foco fijado por el autor, según acabamos de ver en la descripción de encantos personales de Enriqueta en Juan el organista. ${ }^{31}$

Puntos de observación. El mismo asunto puede seguir varios giros conforme al ángulo de observación o punto de vista que adopta el autor. Este puede (a) observar a sus personajes desde fuera, como un espectador perspicaz, tratándoles objetivamente mientras se mueven por la cadena de las circunstancias; (b) penetrar en su mundo interno y revelar sus pensamientos y sentimientos, borrando la acción; (c) contemplar los personajes desde fuera y, llevado de su propio estado de conciencia, conjeturar su vida y su ente espiritual, y (d) presentar el asunto en primera persona como un relato de la figura principal.

En los cuentos de Gutiérrez Nájera hay ejemplos de estos modelos salvo el (a). Su giro favorito, y que emplea ventajosamente es penetrar en la mente del personaje y presentar su sensibilidad espiritual, suspendiendo la acción con este propósito. Muchas veces sacrifica el Duque el hilo de narración, mientras está sumergido en el análisis introspectivo de sus personajes. En los cuentos de Gutiérrez Nájera no hay uno solo que represente el tipo (a) en su entereza, como lo presenciamos en las obras de Stevenson o Poe, sino mezclado con el tipo (b). Este segundo tipo predomina en 
toda la producción, lo que crea el efecto de que "nada pasa" en los cuentos del Duque, para quien la sensibilidad de los personajes y sus reacciones a los acontecimientos de la vida importan más que los propios acontecimientos.

Tomemos como ejemplo a Rip-Rip quien regresa a su aldea después de un largo sueño:

¿Y allá va Rip-Rip con su barba muy cana (que él creía muy rubia), cruzando a duras penas aquellas veredas casi inaccesibles. Las piernas flaquearon... (el autor observa a Rip-Rip desde fuera, no sin dejar una nota del pensamiento del protagonista).

Pero él decía: -iEs efecto del sueño! iY no, era efecto de la vejez, que no es suma de años, sino suma de sueños!

Caminando, caminando, pensaba Rip-Rip:

-iPobre mujercita mía! iQué alarmada estará! Yo no me explico lo que ha pasado..., etc. (el autor penetra en la mente de Rip-Rip, revelando sus pensamientos, mas sin olvidar que le presenta en tercera persona). ${ }^{32}$

Ejemplo de tipo (c) es La novela del tranvia y ejemplos del tipo (d) son Los suicidios y la Historia de una corista.

\section{Introducciones y conclusiones}

Introducciones. Edgar Allan Poe presta gran importancia a la introducción del cuento, la cual, según él, debe poner de manifiesto al efecto concebido. ${ }^{33}$ Los cuentistas de tendencias realistas, como Chejov y Maupassant, suelen empezar el asunto sin preliminares, creando el escenario desde el principio. Gutiérrez Nájera es principalmente un poeta, un lírico en sus tendencias que, a menudo, siente el impulso de vaciar el alma y de compartir con el lector su disposición de ánimo antes de comenzar el relato propio, ligando el espíritu de la introducción al de la parte principal.

El autor muestra cuatro tipos de introducciones en su producción total de cuentos. 
1. En siete cuentos empieza el asunto sin preámbulos presentando al personaje principal, aunque también en éstos es evidente la nota personal: (a) Los amores del cometa (el cometa, mientras pasa por el cielo); (b) Después de las carreras (Berta en el momento de acostarse); (c) Historia de una corista (presenta a la corista por medio de su carta, dedicándola a la edificación de los gomosos) ; (d) Dame de coeur (Rosa-Thé, la antigua amada del autor,cuya tumba le inspira el relato de su trágica muerte); (e) Un 14 de julio (la mexicanita); (f) Crónica de mil colores ("Caperucita color de rosa") ; (g) Historia de un peso falso (el peso falso).

2. E1 modo acostumbrado, empleado por tantos cuentistas, de iniciar la historieta con una descripción que crea un ambiente apropiado, es seguido por el Duque en cuatro de sus cuentos: (a) $\mathrm{La}$ balada de año nuevo (corta descripción de la alcoba donde muere el bebé); (b) La novela del tranvía (descripción del interior del tranvía con sus pasajeros en un día lluvioso); (c) La mañana de San Juan (descripción poética de la mañana de San Juan); (d) Juan el organista (descripción del valle de la Rambla).

3. El artificio favorito del Duque es comenzar el cuento con algunas observaciones personales, pertinentes al asunto que se propone presentar. En esta clase de introducción figura el autor como filósofo, juez y crítico social, aunque siempre con notas sentimentales de poeta y de ser humano. Esta forma es patente en seis cuentos: (a) En el hipódromo (advertencias características sobre los concurrentes de las pistas hípicas); (b) La pasión de Pasionaria (pensamientos tristes acerca de los seres amados muertos que inspiran a los vivientes los fenómenos naturales del viento y de las aguas en las tardes lluviosas); (c) La hija del aire (denuncia de las funciones de circo como degradantes de la dignidad humana); (d) Los suicidios (reprobación de la ligereza de la gacetilla al referir el trágico suicidio de un joven y el pavor del autor ante la epidemia de suicidios); (e) Rip-Rip (el autor filosofa introspectivamente sobre la intensificación de la visión interior cuando están cerrados los ojos); (f) El músico de la murga (meditaciones del autor, cuya aguzada sensibilidad conjetura imágenes casi místicas alrededor del epitafio de Antipater para la tumba de Orfeo $C_{i-g i t}$ le bruit du vent). 
4. Finalmente, el lirismo subjetivo de Gutiérrez Nájera halla su expresión en un tipo de introducción que corresponde tan oportunamente a su temperamento romántico y que fluye en efusiones líricas en forma de cálida dedicatoria a una joven, como en $L a$ venganza de Mylord y en el Cuento triste, ${ }^{34}$ o en recuerdo romántico personal, empapado en tristeza melancólica, como en Dame de coeur, ${ }^{35}$ o, a la inversa, en exaltada emoción, como la que prodiga en el panegírico a $M a y o$ en $E l$ vestido blanco. ${ }^{36}$

Conclusiones. Como en las introducciones a sus cuentos, el Duque Job también revela su personalidad en las conclusiones que emplea para poner fin a sus obras.

1. Cinco de sus cuentos terminan con el desenlace del asunto: (a) Juan el organista:

Y luego, el coro quedó silencioso, mudo el órgano, y en vez de melodías o himnos triunfales se oyeron los sollozos de una niña.

Era Rosita que lloraba sin consuelo, abrazada al cadáver de su padre. ${ }^{37}$

(b) Los sticidios y la Historia de una corista, ambos cuentos en forma epistolar, donde los supuestos autores concluyen, sin que Gutiérrez Nájera haga comentarios personales. Los suicidios: "... Soy un bolsillo vacío y una conciencia sin fe. Cuando el saco no sirve para nada, se rompe. Esto es lo que hago." ${ }^{38}$ Historia de una corista: "... Esta ha sido la primera ciudad en que me tratan como se trata a una señorita. Ya verá usted si tengo razón para estar agradecida." 80 (c) En dos restantes cuentos, (1) La balada de año nuevo y (2) El vestido blanco, el autor se limita, acabado el asunto, a añadir una sola frase final, que devuelve al lector a la tierra: (1) "Dos niños pasan riendo y cantando por la calle: - $\mathrm{i}$ Mi Año Nuevo! 'Mi Año Nuevo!" 10 (2) "Mi amigo, el místico a lo Verlaine y a lo Rod, había dado el último sorbo del ópalo verde que da el sueño y la muerte." ${ }^{41}$ En los demás de la producción hay gran diversidad de conclusiones.

2. En dos cuentos el autor expresa la reacción a su propia creación. (a) En La novela del tranvía que exigió un tremendo esfuerzo de imaginación, observa para concluir: 
Un sudor frío bañaba mi rostro. Afortunadamente habíamos llegado a la plazuela de Loreto, y mi vecina se apeó del vagón. Yo vi su traje: no tenía ninguna mancha de sangre...42

Confiesa que sus sospechas acerca de la existencia de un amante de la señora vecina del tranvia carecen de base puesto que la ve entrar en la iglesia. (b) En La venganza de Mylord, también, el Duque vuelve sobre sí, después de haber conjeturado la vida de peligroso adulterio terminado en la muerte de la hermosa Alicia, a quien imagina ver en el palco presenciando un espectáculo, pero que, como aprecia, sólo guarda cierto parecido con la que mueve su imaginación.

3. Tres cuentos terminan con un recuerdo personal del autor. (a) En el hipódromo se concluye por un recuerdo romántico de una escapada del Duque, verdadera o imaginaria, a caballo, con su amada joven. ${ }^{43}$ (b) En la conclusión de El músico de la murga, Gutiérrez Nájera recuerda la muerte del músico "que parecía la sombra de un paraguas cerrado" 44 y su hondo arrepentimiento por haber pisado la música de aquel desgraciado en los bailes. (c) En la Dame de coeur, al recordar a su antigua amada, se vale el Duque del bien probado recurso, calculado para intensificar la impresión, de reiterar el cuadro que sirve para la introducción:

Allá, bajo los altos árboles del Panteón Francés, duerme la pobrecita de cabellos rubios a quien yo quise durante una semana... ¡ todo un siglo!... y se casó con otro. $\mathbf{4 5}$

(d) En La hija del aire, recordando el autor a la pequeña víctima del comercializado acrobatismo y compadeciéndose de ella, aprovecha de la ocasión para vituperar a la sociedad que descuida a los niños, dejándoles caer en la degradación. ${ }^{46}$

4. El gusto de filosofar tiene su expresión en dos cuentos: (a) En $R i p$-Rip plantea el autor preguntas para las cuales no hay contestación: “¿Cuánto tiempo se necesita para que los seres que amamos y que nos aman nos olviden? ¿Olvidar es delito? ¿Los que olvidan son malos ?" $47 \mathrm{Y}$, puesto que la vida es un enigma, aprueba que Jesucristo resucitara sólo a un hombre, y ése un recién muerto, sin mujer e hijos. Confirma el Duque con una nota sombria: "Es 
bueno echar mucha tierra sobre los.cadáveres." "48 (b). EI pensamiento de la moraleja èn la Crónica 'dé mil colores, la ingeniosa adaptación del bien conocido tema de la "Caperucita Roja", contiene una nota de filosofia burlona: "Hoy ya no es un lobo quien se engulle a la chicuela: la chicuela es quien se engulle al lobo." 49

5. (a) El temperamento flamante y comunicativo del poeta estalla a menudo en forma característica de exhortación a Dios o a los propios personajes de su ficción. Ia fe de Gutiérrez Nájera, aunque debilitada dogmáticaménté por los desengaños de las luchas terrenales, siempre fué una fuerza vital en su carácter, y cuando en sus cuentos más dramáticos, han quedado pintados cuadros de torpe injusticia, que motivan la protesta de toda conciencia, viene una apelación a la Divinidad, (1) en forma de fervorosa plegaria, como en Un 14 de julio: “. . . Señor, ¿ en dónde está la pobre mexicana? ; Si vive aún, dale la muerte de limosna!" so (2) en un reproche a Dios, no pudiendo resignarse a que no obrara con justicia, cual en la Historia de un peso falso:

iSeñor! Tú que trocaste el agua en vino: tú que hiciste santo al ladrón Dimas; ‘ por qué no te dignaste convertir en bueno el peso falso de ese niño? ¿Por qué en manos del jugador fué peso bueno, y en manos del desvalido fué un delito? ... Tú que cegaste a Saulo en el camino de Damasco, ¿ por qué no cegaste al espafiol de’ aquella tienda? 01

(3) O, simplemente, en una pregunta al Ser Supremo que no pide? respuesta, como en La pasión de Pasionaria: “ ¡ Dios mío! ¿ cuándo. se acaba el mundo para que no estén ausentes esas pobres almas?..." 52 (b) Menos dramática, aunque sumamente expresiva: también, es la apelación del poeta a los personajes, humanos o sobrenaturales humanizados, creados en sus obras. Así, en el Cuento tris$t e$, dirigiéndose a su antigua amada con un razonamiento de romántica melancolía, le dirige consejos morales de un experimentado, acompañando algunos de epigramas filosóficos:

- ¿Ya lo ves? La vida mundana, tan brillante por fuera, es como los sepulcros blanqueados de que nos habla el Evangelio. La riqueza oculta con su manto de arlequín muchas miserias. 
Cierra tus oídos a las palabras del eterno tentador. No ambiciones el oro, que es tan frío cotno el corazón de una coqueta. Sé buena, reza mucho y ama poco. 53

En los cuentos que terminan con apelación a las entidades humanizadas este recurso es simplemente un "tour de force" poético. Estos son: (1) Después de las carreras:

No entres -ioh fría luz!- no entres a la alcoba en donde Manón sueña con el amor y la riqueza. ¡ Deja que duerma, con su brazo blanco pendiente fuera del colchón, como una virgen que se ha embriagado con el agua de las rosas. Deja que las estrellas bajen del cielo azul, y que se prendan en sus orejas diminutas de porcelana transparente! 54

(2) Los amores del cometa:

Pero vosotras no lo poseeréis, joh estrellas enamoradas! Ya sabe que otros de sus compañeros se han perdido por acercarse mucho a los planetas. Como los hombres cuando se enamoran, se han casado. Perdieron su independencia desde entonces, $y$ hoy gravitan siguiendo una cerrada curva o una elipse. Por eso huye y esquiva vuestras redes de oro; ies de la aurora! Miradle cómo espía a su rubia amada por la brillante cerradura del Oriente: El cielo empieza a ruborizarse. ¡Ya es de día! Las estrellas se apagan en el cielo, y los ojos que yo amo se abren en la tierra. 55

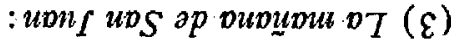

";Oh mañanita de San Juan! ¡ Tu blanco traje de novia tiene también manchas de sangre "' 56

(Continuará)

\author{
Alexander Kosloff, \\ Los Angeles, California.
}

$\mathrm{NO}$ T A S

1 Sean O'Faolain, The Short Story. (New York: The Devin-Adair Company, 1951), p. 30.

2 Cf. pp. 66 y 75 , de la tesis. 
3 Federico de Onís, "El cuento de España" John M. Hill and Erasmo Buseta, Antologia de cuentos españoles. (Boston: C. Heath and Company, 1923), p. vir, prólogo.

4 Ruby V. Redinger, "Short Story. Characteristics", Encyclopedia Americana, xxiv, 746.

5 H. E. Bates, The Modern Short Story (Boston: The Writer, Inc, 1941), p. 26.

6 The Book of Poe. Edgar Allan Poe, Excerpts from On Prose Writing. Hawthorn and the Story-Teller's Art. In Godey's Lady's Book. November, 1847, p. 124.

7 Guy de Maupassant, "Pierre et Jean" (Paris: Société d'éditions littéraires et artistiques, (s. $d . \mathrm{I}), \mathrm{pp} .11-12$.

8 Ibid., p. 13. Citado en la traducción inglesa en O'Fnolain, op. cit., pp. 132-133.

9 "El músico de la murga", Obras de Manuel Gutiérrez Nójéra, prosa, Cuentos color de humo, tomo primero. (México: Tip. de la Oficina Impresora del Timbre, Palacio Nacional, 1898), pp. 88-89.

10 "Los suicidios", Obras de Manuel Gutiérres Nájera, prosa, Cuentos frágiles, op. cit., p. 50.

11 Cf. post., apéndice, pp. 333-335.

12 Iván Sergueevich Turgueneff, novelista ruso (1818-1883).

13 CE. post., apéndice, pp. 337-338.

14 Cf. ante, pp. 174-180 y 182-188, de la tesis.

15 Cf. ante, pp. 124-126, de la tesis.

16 "Un 14 de julio", Manuel Gutierrez Nájera, Cuentos color de humo. (México: Editorial Stylo, 1942), p. 61.

17 Loc, cit.

18 Ibid., p. 62.

19 Loc. cit.

20 Ibid., p. 65.

21 C. "Juan el organista", Manuel Gutiérres Näjera, Cuentos color de humo, op. cit., pp. 26-27.

22 "Crónica de mil colores", Obras de Manuel Gutiérrez Nájera, prosa, Cuentos color de humo, tomo primero, op. cit., pp. 100-109. 
23 "Los suicidios", op. cit., pp. 49-51.

24 "Historia de una corista", Manuel Gutiérrez Nájera, Cuentos frágiles, op. cit., pp. 127-132.

25 "La balada de año nuevo", Manuel Gutiérrez Nájera, Cuentos frágiles, op. cit., p. 112.

26 "Juan el organista", op. cit., p. 38.

27 Loc. cit.

28 Ibid., p. 39.

29 "El vestido blanco", Mamel Gutiérrez Nájera, Cuentos color de humo, op. cit., p. 15.

30 "Un1 14 de julio", op. cit, p. 65.

31 C. ante, pp. 237-238, de la tesis, cita 26.

32 "Rip-Rip", Manuel Gutiérrez Nájera, Cuentos color de humo, op. cit., p. 12 .

33 The Book of Poe, loc. cit.

34 Cf. ante, pp. 123-124.

35 Cf. ante, pp. 119-120.

36 Cf. ante, pp. 210-211.

37 Cf. ante, pp: 117-118.

38 Cf. ante, pp. 204-205.

39 Cf. ante, p. 174.

40 Cf. ante, p. 157.

41 "El vestido blanco", op. cit,, p. 20.

42 "La novela del tranvia", Manuel Gutiérrez Nójera, Cuentos frágiles, op. cit, p. 108.

43 Cf. ante, p. 193.

$44 \mathrm{Cf}$, ante, pp. 165-166.

45 Cf. ante, pp. 119-120.

46 Cf. ante, pp. 160-161.

47 Cf. ante, pp. 141-142.

48 Cf. ante, p. 137. 
49 Cf. ante, pp. 151-152.

50 Cf. ante, p. 125.

51 Cf. ante, pp. 127-128.

52 "La pasiỏn de Pasionaria", Obras de Manuel Gutiérrez Nájera, presa, Cuentos frágiles, tomo primero, op. cit., p. 31.

53 "Cuento triste", Manuel Gutiérrez Nájera, Cuentos color de humo, op. cit., p. 73 .

54 Cf. ante, pp. 199-200.

55 "Los amores del cometa", Mantel Gutiërrez Nájera, Cuentos frágiles, op. cit., p. 86.

56 C. ante, p. 106. 
